\title{
A new method for the histochemical localization of laccase in Rhus verniciflua Stokes
}

\author{
M.R. Li ${ }^{*}$ \\ Department of Forestry and Natural Resources, University of Edinburgh, The King's Buildings, \\ Mayfield Road, Edinburgh EH9, 3JU, Scotland, U.K.
}

\section{Introduction}

There has been great interest in laccase for over $100 \mathrm{yr}$, since Yoshida first detected this copper-containing enzyme in 1883. Laccase (EC 1.10.3.2) is found in the latex of species of Rhus and is responsible for the oxidation of phenol urushiol, which is contained in the latex, with production of the black resinous lacquer (Bonner, 1950). Besides Rhus, laccase is also found in numerous other woody plants including Aesculus sp., Prunus persica, Acer pseudoplatanus and many species of the Anacardiaceae family, and in a number of fungi as well as in some herbaceous plants (Bonner, 1950; Butt, 1980; Mayer and Harel, 1979; Bligny and Douce, 1983). Although it is moderately widely distributed in higher plants and there have been many reports concerning its biochemical and biophysical properties, laccase has benefitted from little or no investigation, and in the literature there are no speculations as to its physiological function in the secretory ducts of Rhus. One of the main difficulties encountered in studying its physiological function may be the inactivation of the enzyme during extraction and purification; its substrate, urushiol, is apparently necessary for maintaining it in an undenatured state (Guo, 1981).

Laccase can be demonstrated in vitro by means of biochemical methods, such as spectrophotometry, oxygen-absorbance and polarography from the liquid lacquer or from a cell-cultured suspension (Guo, 1981; Gan and Gan, 1983; Bligny and Douce, 1983). For the purpose of studying its physiological function in the lacquer tree, a simple permanent staining technique for in situ laccase fixation has been developed, which permits its enzymatic activity to be maintained in vivo and the stable product of the catalysis to be distinguished under the light microscope.

\section{Materials and Methods}

One year old seedlings of the lacquer tree (Rhus verniciflua Stokes cv. Puchengxiaomu) were grown from root-cuttings in pots under good growth conditions. Lignified stems were then processed in the experiment as described below.

\footnotetext{
* Present address: Department of Botany, Trinity College, University of Dublin, Dublin 2, Ireland.
} 


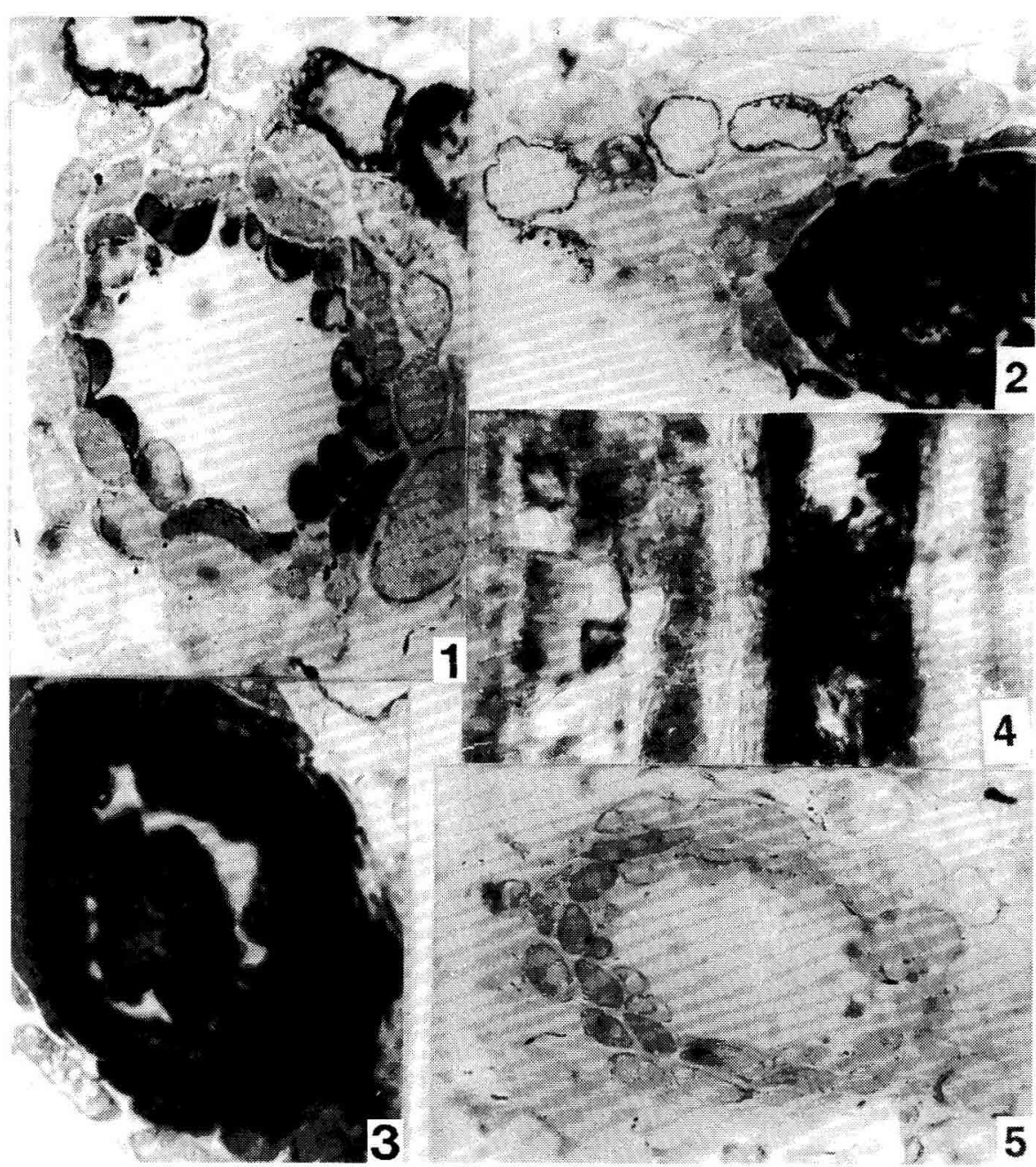

Figs. 1-5. Photomicrographs of stem sections of $R$. vernicuflua Stokes. 1. A fixed latex canal demonstrating laccase in transverse section. A heavy deposit can be seen in the epithelial cells and in outline lateral aspects of some parenchymatous cells $(x$ 936). 2. A transverse section of latex-filled canal. Both the latex droplets and latex-filled canal have a very dark brown deposit, but not the space between the latex droplets (see 3 and 4). (x 858). 3. As in 2 , there is heavy staining of latex droplets and the sheath cells can be seen ( $x$ 1092). 4. Unfixed longitudinal section of a latex-filled canal ( $x$ 593). 5. A control; a transverse section of a latex canal without $p$-dihydroxybenzene staining ( $x$ 858).

\section{Incubation}

Freshly cut blocks (about $1 \mathrm{~mm}$ in width) of the phloem tissue were incubated in $0.05 \mathrm{M}$ phosphate buffer $\left(\mathrm{pH} 7.4,5^{\circ} \mathrm{C}\right)$ for $1-2$ min before staining for $30 \mathrm{~min}$ at $37^{\circ} \mathrm{C}$ in a newly prepared substrate solution of $0.05 \mathrm{M}$ phosphate buffer with $0.01 \%(w / v) p$-dihydroxybenzene $(\mathrm{pH} 7.4)$. In the control treatment, either stem cuttings were denatured by leaving them in water at $100^{\circ} \mathrm{C}$ for $5 \mathrm{~min}$ before cutting into blocks, or 
freshly prepared blocks were incubated in the same buffer without the $p$-dihydroxybenzene.

\section{Prefixation and postfixation}

Foliowing incubation, the blocks were rinsed in $0.05 \mathrm{M}$ phosphate buffer $(\mathrm{pH} 7.4)$ and then transferred into buffered glutaraldehyde $(3 \%)$ at $4^{\circ} \mathrm{C}$ for $1 \mathrm{~h}$. After fixation, they were rinsed in 3 changes of the $0.05 \mathrm{M}$ phosphate buffer with 1 $\mathrm{h}$ for each change. $2 \%$ osmic acid in the same buffer was used at $4^{\circ} \mathrm{C}$ for $2 \mathrm{~h}$.

\section{Embedding and sectioning}

After fixation, the blocks were rinsed 3 times in distilled water before dehydration in ethanol and embedded in Epon 812. Thin sections (1-2 $\mu \mathrm{m}$ thick) were prepared by using a manually operated ultramicrotome (LKB Nova V). For comparison, a parallel study was made using unfixed hand-sections (25-50 $\mu \mathrm{m}$ thick) and frozen sections (10-15 $\mu \mathrm{m}$ thick). The microtome stage and knife were frozen with a semiconductor freezer.

\section{Results}

A heavy deposit can be seen (Figs. 1-4) in the latex canals and some other cells, such as sheath cells, epithelial cells and some parenchymatous cells. The brown deposit in the sections indicates that the reaction product of laccase catalysis is mainly distributed in the canals and their sheath cells, epithelial cells and the ducts with latex droplets. In the control section, almost no deposit can be seen in the canals and surrounding cells (Fig. 5). The deposit is stable and the embedded material can be stored for at least $3 \mathrm{mo}$. In comparison with the unfixed section, the fixed section can be observed more clearly under the light microscope because it is thinner than both the hand-section and the frozen section. The section embedded in Epon 812 is also suitable for study under the transmission electron microscope.

\section{Discussion and Conclusion}

An interesting comparison can be made between histochemical and biochemical methods of enzyme demonstration. All laccases previously described catalyze the following reactions:

p-dihydroxybenz:ene (colorless) laccase $\underset{\text { quin- }}{\longrightarrow}$ hydrone (dark brown) $+\mathrm{H}^{+}$

urushiol (colorless) laccase quin-urushiol (light brown) $+\mathrm{H}^{+}$

Reaction (1) is characteristic of laccase and is the main criterion according to which the enzyme is classified (Mayer and Harel, 1979). Reaction (2) is one of the significant features of laccase in Rhus species. The brown deposit in the sections indicates the localization of active laccase in situ. Activity of laccase is also stimulated by its natural substrate but the product does not show enough contrast for observation. Figs. 1-4 show that the distinguishable reaction product of the artificial reagent $p$-dihydroxybenzene does not dissolve during these preparatory steps.

Using polyacrylamide gel electrophoresis, two laccase isoenzymes with different $R_{\mathrm{f}}$ have been isolated and identified by several phenols, including p-dihydroxybenzene, from the phloem of $R$. verniciflua ( $\mathrm{Li}$, unpublished). Whether these isoenzymes have different physiological functions needs further investigation. The histochemical method described in the present paper may be used to bridge these gaps.

In the lacquer tree, laccase may play a role in sealing-off damaged tissue. It could also be involved in a defense mechanism against pathogens by oxidizing endogenous phenols (e.g., urushiol) to the resultant toxic quinones (Mayer and Harel, 1979; Butt, 1980). Since laccase has been 
shown to be involved in the oxidation of lignin by fungi and there is extensive excretion of laccase by cultured cells of Acer pseudoplatanus, Bligny and Douce (1983) suggested that it could play an important role in the synthesis and deposition of specific wall substances, such as lignin. It should be noted that the allergic skin reaction of humans to quin-urushiol is still treated as a serious disease in China. Evolutionarily, laccase and its substrates seem to be an adaptation of the lacquer tree for survival in competition with other life forms, including insects, fungi, humans and herbivorous animals. At present, this must be regarded as speculation that is worthy of experimental investigation.

\section{References}

Bligny R. \& Douce R. (1983) Excretion of laccase by sycamore (Acer pseudoplatanus L.) cells. Purification and properties of the enzyme. Biochem. J. 209, 489-496

Bonner J. (1950) In: Plant Biochemistry. Academic Press, New York, p. 182

Butt V.S. (1980) Direct oxidases and related enzymes. IV. Laccase. In: The Biochemistry of Plants. A Comprehensive Treatise. Vol. 2 (Metabolism and Respiration). (Davies D.D., ed.), Academic Press, New York, p. 113

Gan C.J. \& Gan J.G. (1983) Laccase. Chinese Lacquer (Xian) 2 (suppl.) 42

Guo M.G. (1981) The laccase activity measured by oxygen absorbance. Chem. Ind. For. Prod. (Nanjing) 3, 24

Mayer A.M. \& Harel E. (1979) Polyphenol oxidases in plants. Phytochemistry 18, 198-215 